\title{
ANALISA MANAJEMEN DAN STRATEGI BISNIS PADA RESTO IKAN BAKAR DAN KOLAM PANCING WATUKOSEK
}

\author{
Ach. Nur Fuad Chalimi \\ Jurusan Akuntansi, STIE Gempol \\ fuad.stieg@gmail.com
}

\begin{abstract}
ABSTRAK
Resto Ikan Bakar dan kolam pancing merupakan salah satu usaha keluarga yang bergerak dalam bidang rumah makan di Gempol Pasuruan. Penelitian ini bertujuan untuk mendeskripsikan fungsi manajemen, lingkungan internal dan eksternal serta menyusun rencana strategi bisnis di masa mendatang. Penelitian yang dilakukan dengan metode kualitatif ini menggunakan teknik pengumpulan data berupa wawancara ke beberapa orang informan dari pihak rumah makan. Dari hasil penelitian yang telah dilakukan, dapat disimpulkan bahwa Resto Ikan Bakar memiliki kendala pada pengelolaan sumber daya manusia. Dari hasil analisis, strategi bisnis yang tepat digunakan oleh Resto Ikan Bakar di masa mendatang adalah best-value focus yang memiliki fokus terhadap pelayanan dan kualitas produk yang diberikan kepada pelanggan.
\end{abstract}

Kata Kunci : Manajemen, Strategi Bisnis, Analisa SWOT.

\section{PENDAHULUAN}

Dewasa ini, Peluang usaha di bidang wisata kuliner dengan membuat restoran maupun rumah makan adalah satu hal yang patut untuk di pelajari. Dan saat ini gaya hidup untuk berwisata kuliner sudah menjadi bagian dari denyut kehidupan masyarakat kita. Dalam hal makan sekarang ini sudah melebihi hanya sekedar makananya saja namun tempat, pelayanan, lokasi dan menu serta masih banyak lagi aspek pendukung yang menjadikan dasar pendukung masyarakat kita untuk menentukan pilihan tempat makan.
Usaha makanan juga merupakan usaha yang dapat diupayakan dengan memiliki ahli masak yang handal dan pelayanan yang ramah kepada setiap pelanggan. Kualitas dan rasa memang menentukan segalanya. Untuk segi kualitas Anda bisa memaksimalkan dalam pelayanan, keramahan dan kualitas dari produk itu sendiri. Jika rasa dan kualitas sudah bisa diunggulkan, maka dijamin bisnis makanan akan mendatangkan omset maksimal. Untuk menjalankannya memang tidak mudah. 
Beberapa konsep utama yang relevan dalam menganalisa strategi bisnis adalah sebagai berikut :

a. Fungsi Manajemen (Daft, 2009 ; Solihin, 2009 ; Madura, 2007 ; Sumarni dan Soeprihanto, 2005)

Fungsi Manajemen adalah pencapaian tujuan organisasi dengan cara yang efektif dan efisien melalui Planning (menentukan tujuan bagi rumah makan di masa depan serta memutuskan tugas dan penggunaan sumber daya yang diperlukan untuk mencapai tujuan tersebut), Organizing (meliputi organisasi karyawan dan sumber daya lainnya melalui cara yang konsisten dengan tujuan rumah makan), Actuating (tindakan untuk mengusahakan agar semua anggota organisasi melakukan kegiatan yang sudah ditentukan ke arah tercapainya tujuan), dan Controlling (fungsi manajemen yang berkaitan dengan pengawasan aktivitas karyawan, pertahanan organisasi pada jalur pemenuhan tujuan, dan pengoreksian bila diperlukan).

b. Strategi Bisnis (David, 2011)

Strategi memungkinkan organisasi untuk memperoleh keunggulan kompetitif dari tiga landasan yang berbeda, yaitu ; Cost Leadership (menekankan pemroduksian produk yang distandarisasi dengan biaya per unit yang sangat rendah untuk para pelanggan yang peka terhadap harga),

Differentiation (menghasilkan produk atau jasa yang dianggap unik di usaha dan diarahkan kepada pelanggan yang lebih mementingkan kualitas ataupun nilai tambah yang ada pada produk), dan Focuz (memproduksi produk dan jasa yang memenuhi kebutuhan sekelompok kecil pelanggan pada harga terendah yang ada di pasar atau nilai harga terbaik yang ada di pasar).

c. Analisis Internal (David, 2011)

Mengidentifikasi kekuatan dan kelemahan dari masing-masing fungsi bisnis yang ada di rumah makan seperti fungsi pemasaran (segmentasi pasar, market share, kualitas produk, cara promosi produk, serta pengalaman manajer pemasaran sendiri), fungsi keuangan (pembiayaan jangka pendek dan panjang, pembagian deviden, relasi dengan investor, pengalaman manajer keuangan), fungsi operasional (kondisi fasilitas dan peralatan, kualitas dan kontrol 
persediaan), fungsi sumber daya manusia (perekrutan, pelatihan, kedisiplinan dan kompensasi pekerja), dan fungsi sistem informasi manajemen (tingkat kemanan dalam menjalankan sistem informasi, pelatihan bagi karyawan, serta peningkatan performa sistem informasi manajemen rumah makan).

d. Analisis Eksternal (David, 2011)

Dalam lingkungan eksternal terdapat beberapa kekuatan yang dapat memiliki pengaruh terhadap rumah makan. Porter Five Forces Model adalah suatu pendekatan yang digunakan secara luas oleh rumah makan untuk mengembangkan strategi terkait keberadaan kekuatan kompetitif atau persaingan. Secara umum, pendekatan ini digunakan rumah makan untuk mengembangkan strategi terkait kekuatan-kekuatan yang dapat menimbulkan persaingan. PorterFive Forces Model terdiri dari Persaingan antarrumah makan saingan, potensi masuknya pesaing baru, potensi pengembangan produk pengganti, daya tawar pemasok, dan daya tawar pelanggan.

e. Analisis SWOT (Dyck dan Neubert, 2009 ; David, 2011)
Analisis SWOT adalah analisis yang digunakan untuk mengetahui faktor internal dan eksternal yang digunakan untuk mengetahui kekuatan dan kelemahan internal organisasi, serta peluang dan ancaman eksternal. Analisis ini didasarkan pada logika yang dapat memaksimalkan kekuatan (strength) dan peluang (Opportunities), tetapi secara bersamaan dapat meminimalkan kelemahan (weakness) dan ancaman (threats).

f. Usaha Keluarga

Usaha keluarga dicirikan terutama dengan kepemilikan dan keterlibatan yang signifikan dari keluarga dalam manajemen. Pengambilan keputusan dan kebijakan, penyusunan strategi dan kegiatan bisnis sehari-hari dilakukan oleh keluarga.

Resto Ikan Bakar adalah usaha yang bergerak di bidang kuliner di Gempol Pasuruan. Maka dari itu Resto Ikan Bakar juga memerlukan strategi bisnis yang tepat agar dapat mengidentifikasi kekuatan dan kelemahan rumah makan dan dapat menangkap peluang dan mampu meminimalkan ancaman yang ada di masa mendatang. Resto Ikan Bakar sendiri didirikan oleh Bapak Aminin 
yang hingga saat ini masih memimpin rumah makan tersebut. Awal berdirinya rumah makan ini pada tanggal 30 Agustus 2014.

Waktu mulai berjalan dari tahun ke tahun usaha rumah makan mulai mengalami kemajuan yang lumayan pesat sehingga sering mengalami kekurangan ikan segar untuk memenuhi pesanan dari pelanggan sehingga mencari pasokan ikan segar ke petani sekitar agar pelanggan selalu merasakan dengan puas atas pelayanan yang dilakukan.

Berdasarkan fenomena yang ada, penelitian ini dilakukan karena melihat pertumbuhan rumah makan di Indonesia belakangan ini. Hal ini menyebabkan peneliti tertarik untuk meneliti rumah makan Resto Ikan Bakar apakah strategi bisnis yang ada pada rumah makan ini sudah dikelola dengan baik, serta melihat bagaimana strategi bisnis yang seharusnya dilakukan oleh Resto Ikan Bakar di masa mendatang.

\section{METODE PENELITIAN}

Jenis penelitian ini adalah penelitian kualitatif. Menurut Moleong (2007), penelitian kualitatif yaitu penelitian yang bermaksud untuk memahami fenomena tentang apa yang dialami oleh subjek penelitian. Penelitian ini menggunakan metode kualitatif yaitu melalui pengamatan, wawancara atau penelaahan dokumen. Penelitian ini menggunakan kualitatif karena penelitian kualitatif menghasilkan data atau informasi yang sulit dicari melalui metode kuantitatif, tetapi juga mampu menghasilkan informasi-informasi yang bermakna, bahkan hipotesis atau ilmu baru yang dapat digunakan untuk membantu mengatasi masalah dan meningkatkan taraf hidup manusia (Sugiyono, 2011). Pada penelitian ini, studi kasus akan dilakukan pada analisis strategi bisnis pada Resto Ikan Bakar. Teknik penentuan narasumber yang digunakan adalah non-probability sampling. Teknik pengumpula data yang digunakan adalah semistructure interview, dengan jenis wawancara indepth interview dimana pelaksanaannya lebih bebas bila dibandingkan wawancara terstruktur. Tujuan dari wawancara jenis ini adalah untuk menemukan permasalahan secara lebih terbuka. Uji validitas dan reliabilitas menggunakan triangulasi sumber. Teknik analisis data yang digunakan adalah dengan menelaah atau mendeskripsikan seluruh data, 
kemudian mereduksi data yang diperoleh, setelah itu diperiksa keabsahab data yang ada, baru peneliti melakukan penafsiran data yang ada.

\section{ANALISA DAN PEMBAHASAN}

\subsection{Fungsi Manajemen Rumah Makan}

Dalam perencanaannya, rumah makan ingin selalu menjaga kepercayaan pelanggan dengan cara menjaga kualitas hasil produksi yang sesuai dengan pesanan pelanggan, rumah makan memercayai apabila rumah makan dapat menjaga kepercayaan pelanggan, rumah makan akan berkembang dengan sendirinya. Untuk menjaga kepercayaan tersebut, rumah makan melakukan pencatatan data-data mengenai pesanan yang diinginkan pelanggan, sehingga rumah makan dapat mengetahui tentang perincian pesanan pelanggan yang ada. Dan dalam menjaga kualitas hasil produksi, pemilik rumah makan selalu mengawasi operasional dalam rumah makan, baik dalam pemilihan bahan baku, sampai dengan pengawasan sebelum diantar ke pelanggan, dicocokkan dengan data pesanan pelanggan apakah sudah sesuai dengan pesanan pelanggan atau tidak.

Organizing, untuk menjaga hubungan antara berbagai fungsi dan faktor-faktor fisik yang ada dalam rumah makan, rumah makan membagi tugas antara karyawan yang satu dengan yang lainnya agar setiap karyawan memiliki fokus sendiri dengan tugas yang mereka terima. Jadi proses yang ada tidak terganggu dengan banyaknya pesanan pada rumah makan. Sebelum pembagian tugas diberikan kepada para karyawan, dalam perekrutan, rumah makan selalu memberikan pelatihan kepada karyawannya dalam menjalankan tugas, agar dalam pelaksanaannya, mereka dapat bekerja dengan baik sesuai dengan yang diharapkan rumah makan dan pelanggan. Untuk mengkoordinasikan tugas yang berbeda dalam rumah makan untuk mencapai tujuan bersama, rumah makan memiliki tolak ukur yaitu dengan melihat hasil yang dicapai oleh karyawan tersebut dan akan mengevaluasi di mana letak kekurangan dalam pembagian tugas tersebut. 
Actuating, untuk menjaga tercapainya tujuan rumah makan, pemilik rumah makan memberikan gaji kepada pegawainya sesuai dengan hasil yang dicapai dalam satu bulan. Pemilik rumah makan juga memberikan bonus kepada karyawan agar selalu giat dalam menjalankan pekerjaan sesuai dengan bagiannya. Pemilik rumah makan juga memberikan motivasi dengan cara mendekatkan dan memperlakukan mereka seperti keluarga sendiri, sehingga mereka juga ikut merasa memiliki rumah makan ini. Jika mereka merasa bahwa rumah makan ini juga milik mereka, mereka akan bekerja dengan baik karena mereka juga pasti ingin rumah makan ini menjadi semakin maju dan berkembang. Dalam melakukan pengarahan, tugas dan instruksi dalam melakukan implementasi kerja, pemilik rumah makan selalu melakukan pengawasan dalam setiap proses produksi, sehingga apabila dalam proses produksi ada yang kurang tepat, pemilik rumah makan dapat langsung memberikan arahan, sehingga kesalahan dalam proses produksi dapat diminimalisasi.
Controlling,

untuk mengawasi, memonitor kinerja dan aktivitas karyawan dalam rumah makan, karyawan dinilai dari kinerja yang mereka kerjakan apakah sudah sesuai dengan kebutuhan atau tidak, apabila pekerjaan mereka tidak sesuai kebutuhan, berarti mereka tidak bekerja dengan baik. Sedangkan untuk administrasi, pemilik rumah makan selalu mengontrol hasil kerja mereka setiap pulang kerja. Dan untuk melihat apakah rumah makan sudah memenuhi keinginan para pelanggan atau tidak, rumah makan selalu memberikan selembaran kertas untuk diisikan sebuah komentar dan dimasukkan kotak saran sebalah tempat administrasi pada saat melakukan pembayaran. Pemilik rumah makan juga melihat dari segi jumlah omzet yang didapat oleh rumah makan. Hal ini dievaluasi oleh pemilik rumah makan setiap satu minggu sekali. Dengan melihat jumlah omzet, rumah makan juga menggunakan sebagai alat ukur prestasi kinerja rumah makan secara keseluruhan dan kinerja karyawan. 


\subsection{Analisa Faktor Internal}

- Sumber Daya Manusia

Perekrutan karyawan di Resto Ikan Bakar ini tergolong sederhana, biasanya jika rumah makan membutuhkan tenaga kerja melalui orang-orang disekitar yang mengerti tentang kuliner atau memberi info ke sekolahan yang ada jurusan tata boga sehingga para tenaga kerja yang masuk sedikit banyak mengetahui tentang olahan makan yang akan disajikan ke para pelanggan. Dalam hal pelayanan, pemilik perusahaan bekerja sama dengan sekolahan sekitar yang ada jurusan perhotelan sehingga dalam segi pelayanan dapat terlaksana dengan baik dan para siswa sekolahan tersebut bisa mengaplikasikannya secara langsung dari terori yang di dapat pada saat di sekolah. Sedangkan untuk administrasi, pemilik rumah makan menggunakan jasa dari saudara dan kawan untuk mencarikan tenaga yang handal dan jujur di bidangnya kemudian baru diinterview di rumah makan apakah calon karyawan tersebut layak bekerja atau tidak.
- Operasional

Dalam sistem produksi, fasilitas dan peralatan yang digunakan merupakan komponen penting dalam prosesnya, sehingga rumah makan merasa perlu dalam melakukan perhatian khusus di bidang ini. Salah satu perhatian khusus yang diberikan oleh rumah makan adalah menjamin selalu atas ketersediaannya ikan segar yang akan di olah apabila pelanggan banyak yang berdatangan sehingga para pelanggan tidak merasa kecewa. Dengan banyaknya produksi tersebut, rumah makan harus memperhatikan kualitas barang yang ada, dengan melakukan kontrol kualitas terhadap ikan segar yang akan diolah atau yang akan di peroduksi.

- Keuangan

Pengelolaan keuangan rumah makan yang selama ini sudah dilakukan adalah dengan melihat omzet rumah makan, cash flow dan pengeluaran bulan sebelumnya. Untuk mencapai kinerja keuangan yang baik rumah makan didasarkan pada 
didasarkan peningkatan pada omzet dan pengeluaran bulan sebelumnya. Selanjutnya, rumah makan mengukur kinerja keuangan rumah makan dengan mengevaluasi hasil pada omzet, cash flow dan pengeluaran bulan sebelumnya yang dicapai apakah sudah sesuai apa belum. Caranya adalah dengan mengevaluasi hasil yang dicapai dan melakukan audit.

- Sistem Informasi Manajemen Sistem Informasi Manajemen yang ada di Resto Ikan Bakar bersifat sederhana. Rumah makan hanya melakukan integrasi data laporan keuangan dengan menggunakan program aplikasi Microsoft Excel dalam menghasilkan data dan informasi yang akan disampaikan pada pemilik untuk pengambilan keputusan internal maupun eksternal.

\subsection{Analisa Faktor Eksternal}

- Persaingan antar rumah makan saingan

Dalam menghadapi persaingan yang ada, rumah makan memiliki keuntungan yang lebih karena rumah makan mampu menghasilkan produk yang lebih baik dengan harga yang sama dengan pesaing, hanya rumah makan belum memiliki pangsa pasar sebesar yang dimiliki oleh rumah makan saingan. Rumah makan juga selalu menjaga hubungan baik dengan pelanggan agar pelanggan tidak pindah ke rumah makan pesaing.

- Potensi masuknya pesaing baru

Produk yang dihasilkan rumah makan merupakan produk yang standar dan hampir tidak memiliki diferensiasi. Hal ini menyebabkan mudahnya pesaing baru untuk memasuki usaha kuliner ini, karena dengan memiliki alat yang ada, serta sumber daya manusia yang cukup, sudah dapat mendirikan rumah makan ini. Ditambah dengan semakin banyaknya usaha perumahan yang ada di Pasuruan yang mendukung pihak pemasok dalam menambah jumlah ikan segar, karena usaha ini banyak menggunakan ikan segar yang diolah oleh pihak pemasok. Sedangkan untuk modal awal 
yang diperlukan rumah makan pesaing dalam usaha kuliner ini cukup besar, apalagi jumlah para pelanggan dalam mencari kuliner mulai meningkat dikarenakan kebutuhan yang ada. hal ini juga menjadi salah satu faktor yang ditakutkan rumah makan dalam menghadapi pesaing yang ada. Maka dari itu, rumah makan memiliki shaf handal yang mampu memodifikasi menu ikan bakan di rumah makan sehingga dapat mengimbangi dengan pesaing yang ada.

- Daya tawar pelanggan

Pembeli memiliki posisi penting terhadap keberlangsungan hidup suatu rumah makan. Daya tawar pembeli memberikan pengaruh besar terhadap produk yang ditemui di pasaran. Mayoritas pelanggan Resto Ikan Bakar adalah instansi pemerintahan dan instansi swasta., maka dari itu rumah makan memberikan layanan yang lebih terhadap pelanggannya, dengan harga yang sedikit lebih rendah dalam pasaran. Keinginan pelanggan untuk berpindah ke rumah makan yang lain memiliki kemungkinan yang kecil, karena produk pengganti yang ada di rumah makan lain memiliki harga yang lebih tinggi dibandingkan dengan produk rumah makan. Para pelanggan sudah terbiasa untuk mencari informasi yang lengkap mengenai produk rumah makan, tetapi yang mengerti benar akan informasi yang ada biasanya hanya pelanggan-pelanggan lama rumah makan, sedangkan untuk pelanggan baru biasanya memiliki informasi yang terbatas mengenai produk rumah makan dengan rumah makan lain.

\subsection{Analisa SWOT}

Analisa SWOT yang terbentuk dari penggabungan analisa internal dan eksternal menghasilkan beberapa alternatif strategi, yaitu :

a. Berfokus pada suatu pangsa pasar dengan menggunakan produk yang telah ada untuk mengembangkan usaha, karena melihat kekuatan yang ada pada rumah makan, rumah makan sudah mampu melakukan pengembangan usaha dengan berbagai dukungan dari pemasok maupun pelanggan. Rumah 
makan tinggal melakukan fokus kepada mengembangkan kualitas produk dan memenuhi pesanan yang ada.

b. Meningkatkan kualitas SDM dan kemampuan manajerial untuk mengantisipasi pertumbuhan pasar. Dengan melihat kesempatan yang ada dalam rumah makan dan kelemahan yang dimiliki rumah makan, dapat kita lihat bahwa rumah makan memerlukan peningkatan kualitas SDM baik dalam penerapan strategi bisnis, hal ini dapat terus dikembangkan oleh rumah makan agar rumah makan mampu bersaing apabila terjadi peningkatan pesanan dari pelanggan yang ada.

c. Melakukan promosi sebanyak mungkin seiring dengan peningkatan konsumsi ikan segar. Peningkatan produktivitas rumah makan tidak ada artinya jika pemasaran yang dilakukan hanya dilakukan kepada pelanggan yang itu-itu saja, maka rumah makan memerlukan promosi sebanyak mungkin agar rumah makan dapat menangkap pasar yang lebih luas lagi untuk mengembangkan rumah makan.

d. Meningkatkan kemampuan produksi dengan dukungan SDM dan teknologi modern untuk merespon selera pelanggan. Dengan meningkatkan kemampuan produksi suatu rumah makan diperlukan kemampuan SDM yang baik, maka rumah makan juga memerlukan peningkatan produktivitas SDM, didukung dengan teknologi modern agar rumah makan mampu merespon selera pelanggan yang ada.

e. Meningkatkan citra produk dan promosi dalam mengantisipasi masuknya pesaing baru. Menjaga dan meningkatkan mutu produk sesuai dengan spesifikasi yang diminta pelanggan untuk menjaga nama baik dan citra rumah makan, agar pelanggan merasa puas dan tidak terpengaruh dengan masuknya pesaing baru dalam usaha kuliner.

\subsection{Analisa Strategi Bisnis ke Depan}

Menurut peneliti, strategi bisnis yang perlu dilakukan oleh 
pemilik rumah makan Resto Ikan Bakar adalah strategi tipe 5 atau bestvalue focus yang memproduksi suatu produk kepada sejumlah kecil pelanggan dengan nilai tambah terbaik, karena rumah makan ini memproduksi ikan bakar dengan kualitas yang lebih baik ditambah dengan produksi rumah makan yang konstan antara pemesanan pelanggan yang satu dengan pesanan pelanggan yang lainnya, rumah makan juga memberikan jaminan apabila ada produk yang di pesan tidak sesuai dengan yang di pesan pelanggan atau rasanya tidak enak bisa di tukarkan ketentuan yang sudah berlaku di dalam rumah makan, hal ini merupakan nilai tambah bagi pelanggan yang menginginkan kualitas dan pelayanan yang di inginkan. Sehingga strategi yang perlu dilakukan rumah makan ini adalah dengan selalu menambah kualitas dan pelayanan dari hasil produksinya.

\section{PENUTUP}

\subsection{Simpulan}

Berdasarkan hasil penelitian dan pembahasan yang telah dilakukan oleh peneliti, maka dapat diambil beberapa kesimpulan sebagai berikut:

1. Fungsi Bisnis :

a. Planning, rumah makan ingin selalu menjaga kepercayaan pelanggan dengan selalu menjaga kualitas barang hasil produksi.

b. Organizing, rumah makan melakukan pembagian tugas yang berbeda-beda terhadap karyawan, agar karyawan memiliki fokus sendiri-sendiri terhadap pekerjaan yang mereka terima.

c. Actuating, Rumah makan memberikan kompensasi dan bonus kepada karyawan yang melakukan pekerjaan dengan baik sesuai dengan ketentuan yang telah ditetapkan.

d. Controlling, rumah makan menilai dan memonitor kinerja karyawan dengan melihat hasil yang mereka kerjakan dalam rumah makan.

2. Hasil analisa dengan matriks SWOT memberikan alternatif strategi yang dapat diterapkan yaitu:

a. Meningkatkan kualitas produksi untuk meningkatkan daya saing produk.

b. Meningkatkan kualitas SDM dan kemampuan manajerial untuk 
mengantisipasi pertumbuhan pasar.

c. Membina hubungan baik dengan para pemasok dan pelanggan, serta meningkatkan hubungan baik dengan pelanggan yang baru.

d. Menciptakan lingkungan kerja yang lebih kondusif agar dapat meningkatkan kinerja para karyawan.

e. Meningkatkan citra produk dan promosi dalam mengantisipasi masuknya pesaing baru

3. Selanjutnya strategi yang tepat untuk diimplementasikan sesuai dengan kondisi rumah makan adalah strategi fokus yaitu rumah makan lebih berkonsentrasi pada peningkatan pelayanan yang diberikan kepada pelanggan yang baru.

\subsection{Saran}

Saran yang dapat diberikan oleh peneliti adalah :

1. Mempertahankan olahan produk atau menambah menu baru dan pelayanan yang diberikan kepada pelanggannya.

2. Kegiatan promosi produk agar lebih ditingkatkan untuk mengingatkan para pelanggan mengenai citra rumah makan dan produk yang dihasilkan,

$$
\begin{aligned}
& \text { misalnya mendaftarkan rumah } \\
& \text { makan ke media online yang } \\
& \text { menyediakan fasilitas untuk rumah } \\
& \text { makan melakukan promosi. }
\end{aligned}
$$

\section{DAFTAR PUSTAKA}

Amsyah, Zulkifli (2005). Manajemen Sistem Informasi. Jakarta : Garamedia Pustaka Utama.

Barney, (2001). Firm Resources and Sustained Competitive Advantage, Journal of Management,17 (March), 99-120

Daft, Richard L. (2009). Manajemen (6th ed., Vol. 1). (Edward Tanujaya dan Shirly Tiolina, Trans.). Jakarta: Salemba Empat.

Daft. Richard L. (2010). New Era of Management (9th edition). SouthWestern: Cengage Learning.

David, Fred R.(2011). Manajemen Strategis : konsep. Edisi 10. Salemba Empat. Jakarta.

Dyck, B., \& Neubert, M. J. (2009). Principles of Management. International Edition: Cengage Learning.

Ebookbrowse (2012), Jurnal Analisis Manajemen Strategik McDonalds Onny Yuwono Retrieved May, 2013, from http://ebookbrowse.com/jurnalanalisis-manajemen-strategikmcdonalds-onny-yuwono-pdfd484965469

Gasperz, Vincent. (2003). Total Quality Management. PT. Gramedia Pustaka Utama. Jakarta 
Gunawan, Jonathan, (2013) Jurnal Analisa Manajemen dan Strategi Bisnis, from 36180-ID-analisamanajemen-dan-strategi-bisnispada-ud-cahaya-abadi-indah-disurabaya.

Hasibuan, Malayu S.P. (2006). Manajemen: Dasar, Pengertian, dan Masalah. Bumi Aksara. Jakarta

Madura, Jeff. (2007). Pengantar Bisnis (4th ed., Vol. 1). (Ali Akbar Yulianto dan Krista). Jakarta: Salemba Empat.

Moleong, L,J. (2006). Metode Penelitian Kualitatif. Remaja Rosdakarya. Bandung

Pefindo (2012), Profil Usaha PT. Berlina, Tbk. - Pefindo, from http://new.pefindo.com/files/valua si/2012-09-07-brna-01-id.pdf

Sekaran, Uma. (2007). Metodologi Penelitian untuk Bisnis. Edisi 4. Salemba Empat. Jakarta

Solihin, I. (2009). Pengantar Manajemen. Jakarta : Erlangga

Sugiyono. (2011). Metode Penelitian Kuantitatif, Kualitatif, dan $R \& D$. Alfabeta. Bandung.

Sumarni, Murti dan John, Soeprihanto. (2010). Pengantar Bisnis: DasarDasar Ekonomi Rumah makan. Yogyakarta: Liberty.

Susanto, A.B., Wijanarko, (2007). Family Business. The Consulting Group. Jakarta. 